\title{
RESENHA \\ INTELIGÊNCIA ARTIFICIAL: SUA NATUREZA E FUTURO
}

Maria Helena Rocha Antuniassi ${ }^{1}$

\section{BARROSO, Joao Carlos. Norte Araguaia: Territórios e Conflitos. Belém: NAEA. 2019. 270 p.}

O livro em questão discute a estrutura, a história e os problemas atuais vivenciados pela microrregião Norte do Araguaia ${ }^{2}$. O conteúdo é apresentado em três partes e nove capítulos cujos títulos indicam com clareza os problemas a que se referem:

\section{Parte I - Deslocamentos e territorialização no Norte Araguaia}

1 - Fluxos migratórios do "NORTE” para os varjões do Araguaia - João Carlos Barroso (coordenador do NERU/UFMT),

Diante do avanço das empresas agropecuárias, muitos pequenos agricultores, optaram pela migração evitando assim a proletarização, o norte Araguaia faz parte das regiões que receberam essas populações, que atualmente são novamente pressionadas pela expansão da soja, fazendo com que a história dessas populações seja sempre de expropriações e recomeços. Com muita propriedade o autor pergunta "Até quando?" (pág. 47)

2 - O processo de esbulho territorial, silencia mento e a luta pelo reconhecimento étnico dos Kanela do Araguaia e aldeia Tapiraka em Santa Terezinha, Mato Grosso - Paulo Sergio Delgado (antropólogo) e Juliana Cristina da Rosa (historiadora) NERU/UFMT

Este texto se refere ao violento processo de expulsão de grupos indígenas do sul do Maranhão em direção às terras do Araguaia Mato-Grossense, como parte da história de grupos que, a partir do início deste século, buscam reconhecimento étnico e direitos de território.

3 - A problemática da desterritorialização do pequeno produtor na microrregião Norte Araguaia mato-grossense Beatriz dos Santos de Oliveira Feitosa (historiadora) NERU/UFMT

Com base em uma criteriosa analise bibliográfica e de documentação, a autora discute o papel 'desterritorializador' do Estado e seus reflexos na constituição da história de diversos municípios da região em questão. Analisa o documento da EMBRAPA (2014) sete teses sobre o mundo rural brasileiro, ressaltando suas contradições.

\footnotetext{
${ }^{1}$ NAP-CERU/USP

${ }^{2}$ Microrregião do Norte Araguaia - 14 municípios - População de 132;443 hab .Área - 82;042;918 KM2 (https://www.cidade-brasil.com.br/microrregiao-do-norte-araguaia.html )
} 
Parte II - O conflito de Marãiwtsédé,

1 - Apropriação da terra indígena de Marãiwtsédé Armando Wilson Tafner Junior (doutor em Desenvolvimento Socioambiental) e Fabio Carlos da Silva (NAEA/UFPA)

O texto analisa a chegada do capital às terras Xavante, mostrando que o processo de ocupação pode ser entendido como um patrocínio do poder público aos grandes grupos econômicos. "Nos projetos aprovados pela SUDAM destinados ao Pará e a Mato Grosso pode-se constatar que o Instituto de Colonização e Reforma Agraria (INCRA) e a Fundação Nacional do Índio (INCRA) emitiram certidões atestando que não havia índios e posseiros nos locais de execução dos projetos" (pág. 101)

2 - A luta pela terra posseiros do posto da MATA: do sonho da terra ao pesadelo da desintrusão. (1916-2015) Elioni Barros dos Santos

O texto, fartamente ilustrado com fotos (algumas do arquivo pessoal da autora), tem por base uma pesquisa qualitativa que reúne, uma série de depoimentos descrevendo o movimento de resistência e a luta inglória dos posseiros do posto da Mata, para permanecer nas terras ocupadas. "Assim pouco a pouco os posseiros foram deixando a área levando o que podiam retirar, porém muita coisa ficou para trás..."

3 - O processo histórico de renitente esbulho dos Xavantes da TI Marãiwtsédé, e sua relação com a tese do marco Temporal: Juliana Cristina da Rosa (historiadora) e Paulo Sergio Degadoe (antropólogo) NERU/UFMT

Este texto mostra como a narrativa histórica é capaz de fornecer elementos analíticos para contextualizar a luta pela terra de Marãiwtsédé, desde a remoção dos Xavantes em 1966 até a remoção dos posseiros em fins de 2012, a partir de elementos empíricos que permitem problematizar o conceito jurídico de renitente esbulho e a tese do Marco Temporal.

Parte III - Trabalho, Assentamentos Rurais e Agricultura familiar

1 - Avanço do capital e suas implicações nas relações de trabalho rural na microrregião do Norte Araguaia Mato-grossense - Beatriz dos Santos de Oliveira Feitosa(historiadora)NERU/UFMT e Rogerio Rego Miranda (geógrafo) UNIFESSPA/Campus de Marabá)

Para refletir sobre o avanço do capital e suas implicações nas relações de trabalho rural na microrregião estudada os autores se apoiam na teoria marxista e reflexões de autores contemporâneos, como HAESBAERT e DAVID HARVEY, o que revela e ressalta a continuidade das reflexões e narrativas de um artigo a outro na composição do conteúdo do livro.

2 - A produção de leite por agricultores familiares frente a expansão da produção de grãos no município de Canabrava do Norte, Mato Grosso e sua relação com a economia 
local - Luiz Antônio Barbosa Soares(historiador) e Jhony Neves de Souza (sociólogo) UNEMAT.

O artigo em questão discute a constituição histórica do espaço regional sobretudo do município de Canabrava do Norte tendo em vista os assentamentos rurais ${ }^{3}$ e a consequente luta que se estabelece na região visando a obtenção da regularização fundiria e permanência na terra dos agricultores familiares assentados ressaltando as ações do INCRA e do PRONAF na dinâmica desta constituição. Nesses primeiros anos do século XXI, a região vem sendo impactada pela penetração da produção de soja e milho pelo agronegócio. Segundo os autores, a partir dos dados sobre o município de Canabrava do Norte, constata-se que "o aumento da produção da agricultura mecanizada de soja e milho não provocou a redução das culturas de arroz, feijão e mandioca praticada pelos agricultores familiares hipótese levantada inicialmente pelos autores do projeto." (p. 234)

3 - A luta pela terra nos projetos de assentamento do INCRA de Vila Rica-MT (19802010) - Maria do Rosário Soares Lima (historiadora) UNEMAT.

Tendo por base dados estatísticos do INCRA, fontes documentais e depoimentos orais, a autora discute a luta pela terra nos assentamentos ali localizados, em numero de oito, ressaltando as ações do Sindicato dos Trabalhadores Rurais do município de Vila Rica que fez a mediação entre os assentados e o Poder Público.

\section{Considerações gerais}

Ao longo dos nove capítulos, os autores registram a história da região desde a ocupação pelos povos indígenas e sua desterritorialização; fluxos migratórios de lavradores, sobretudo maranhenses, paraenses e goianos, a partir de 1920, passando pela atuação da SUDAM nos anos 60, até a atualidade, com a expansão da soja gerando concentração fundiária e os consequentes impactos socioeconômicos e ambientais. Com base em entrevistas e levantamento de dados estatísticos de diferentes órgãos governamentais, os autores mostram como tais processos impactam de forma diversa os vários municípios que compõem a micro região.

Trata-se de uma obra de grande interesse para os historiadores e demais cientistas sociais que estudam a configuração atual da região do Araguaia; resultante da penetração do capitalismo, desde a primeira metade do século vinte; tendo em vista fatores diversos como a apropriação de terras indígenas, os movimentos de lutas, resistência e expulsão de posseiros e os assentamentos rurais nos projetos do INCRA.

2 - Assentamentos rurais podem ser definidos como a criação de novas unidades de produção agrícola, por meio de políticas governamentais, visando o reordenamento do uso da terra; ou a busca de novos padrões sociais na organização do processo de produção agrícola: (a) projetos de colonização; (b) reassentamento de populações atingidas por barragens; (c) planos estaduais de valorização das terras públicas e de regularização possessória; (d) programas de reforma agrária; e (e) criação de reservas extrativistas BERGAMASCO, S.M., NORDER, L.A.C. O que são assentamentos rurais. São Paulo: Brasiliense, 1996. 88p. (Col. Primeiros Passos, 301) 
Finalmente, um processo em andamento de restruturação produtiva comandada pelo agronegócio, com as bênçãos do Estado brasileiro e suas consequências socioeconômicas e ambientais, como desmatamento, desestruturação de grande parte da agricultura familiar, empobrecimento desta população e êxodo rural. 